May 8-12, Flint, Maastricht (Mr J. H. M. Nillesen, mesweg 19, EysWittem, The Netherlands).

May 13-16, International Radiation Protection, Amsterdam (C. E. Rasmussen, Interuniversitair Reactor Institute, Berlageweg 15, Delft, Netherlands).

May 14-15, Ionic Polymers, Brunel University (Mrs R. Saunders, Industrial Liaison Bureau, Brunel University, Kingston Lane, Uxbridge UB8 3PH, Middlesex, UK).

May 15-16, Ethical and Social Questions Posed by 'Engineering' the Human Genome, New York (Conference Department, The New York Academy of Sciences, 2 East 63rd Street, New York, New York 10021).

May 25-28, Genetic Hazards to Man from Environmental Agents, Ottawa (Mrs J. Renaud, Room 1-5, Health Protection Building, Health and Welfare Canada, Tunney's Pasture, Ottawa, K1A 0L2, Ontario, Canada)

May 26-30, Prostaglandins, Florence (Dr G. C. Folco, Institute of Pharmacology and Pharmacognosy, University of Milan, Via Andrea del Sarto, 21, 20129 Milan, Italy).

May 28-30, Asthma and Allergy, Denver, Colorado (Elliott Middleton, Jr, MD, National Asthma Center, 1999 Julian Street, Denver, Colorado 80204).

May 30-31, Myasthenia gravis, New York (Conference Department, The New York Academy of Sciences, 2 East 63rd Street, New York, New York 10021).

June, Protein Structure and Evolution, Prague (Dr Z. Deyl, Czechoslovak Academy of Sciences, Institute of Physiology, Praha 4-KRC, Budejovická 1083, Czechoslovakia).

June 2-5, Information Transfer in Eukaryotic Cells and Recognition and Responses in Lymphocytes, Montreal (W. Fred Hink, Ohio State University, College of Biological Sciences, Department of Entomology, 1735 Neil Avenue, Columbus, Ohio 43210).

June 2-6, Atomic Masses and Fundamental Constants, Paris (AMCO-5 Secretariat, Institut d'Electronique Fondamentale, Bât. 220, Université Paris-Sud, F-91405 Orsay, France).

June 2-6, Peptides, New York (Conference Department, New York Academy of Sciences, 2 East 63rd Street, New York, New York 10021).
June 4-6, Identification and Role of Cellular Receptor Sites, Baltimore (Edward G. Bassett, Ph.D., Symposium Coordinator, Miles Laboratories, Inc., Elkhart, IN 46514, USA).

June 7-8, Biological Monitoring of Water Quality, Helsinki (Jean-Louis Gaudet, UN Food and Agriculture Organisation, Via delle Terme di Caracalla, 00100-Rome, Italy).

June 9-11, CO.: Metabolism and Productivity of Plants, Madison (Marcia Molldrem, Department of Biochemistry, University of Wisconsin, Madison, Wisconsin 53706).

June 15-18, Plants and Cancer, Baltimore (Dr Ralph N. Blomster, Chairman, Department of Pharmacognosy, School of Pharmacy, University of Maryland, 636 W. Lombard St., Baltimore, Maryland 21201).

\section{Person to Person}

Golfers. Edinburgh Medical Technicians Golfing Society are organising a 50th anniversary Open Golf Tournament at Broomieknowe Golf Club Midlothian on July 8. Prizes to the value of $£ 200$. Open to all Medical and Biological Sciences personnel who hold a national handicap. Entry forms from: David Veitch, MRC Clinical and Population Cytogenetics Unit, Western General Hospital, Crewe Road, Edinburgh EH4 2XU, UK.

New physical and astronomical theory. Scientist wishes to start international organisation to develop a physical and astronomical theory without Einstein's relativity theory, without the quantum theory and without a postulate or principle which is not proved by a positive experiment within ten years. Those wishing to cooperate, contact: Ir P. A. v. Deinse, Adm. v. Gentstr. 9, Utrecht, The Netherlands.

Weight-driven laboratory clock. Wanted, on loan or hire, one of those 'retired' regulator clocks, for a programme of experimental and theoretical work on pendulum and escapement errors. Collection and transport arranged, assurance (if required) against damage or permanent alteration (Dr D. M. A. Mercer, Department of Physics, University of Southampton, SO9 5NH, UK).

There will be no charge for this service. Send items (not more than 60 words) to Robert Vickers at the London office. The section will include exchanges of accommodation, personal announcements, and scientific queries. We reserve the right to decline material submitted. No commercial transactions.

\section{Reports and publications}

\section{Great Britain}

Imperial College of Science and Technology. Sixtyseventh Annual Report of the Governing Body, 1973 (London: Imperial College of Science and Technology, University of London, 1975 .

Psychoeneryetic Systems Vol, 1, Part I, Decenter 1974. Pp. 1-48. Subscription Rates (per volume of four issues, postpaid): Great Britain: Individuals who warrant that the journal is for their own personal use and who order direct from the publishers, £6; Libraries, Institutions and others $£ 22.75$. USA/Elsewhere: Individual subscribers $\$ 19.50 / £ 8.50$. Librarian, Institutions, and others $\$ 58 / £ 25$. (London and New York: Gordon and Breach, Science Publishers, 1974.) [24] Neuropathology and Applied Neurobiology, Vol. 1 No. 1, January 1975. Edited by J. B. Cavanagh. (Journa of the British Neuropathological Society.) Pp. 1-110. Published Quarterly. Annual subscription: £14; USA and Canada $\$ 47.50$. Single issues: $£ 4$; USA and Canada $\$ 13.50$ plus postage. (Oxford and London: Blackwell
Scientific Publications, 1975.)

\section{Other countries} Environmental Impact Assessment: Principies and
Procedures. Edited by R. E. Munn. (SCOPE Workshop on Impact Studies in the Environment (WISE) cosponsored by United National Environmental Program (UNEP), Environment Canada and UNESCO.) Pp. 160. (Toronto: International Council of Scientific Unions Scientific Committee on Problems of the
Environment, 1975.)

New Zealand Meteorological Service. Misc. Pub. No. 109: Meteorological Observations for 1973-Stations in New Zealand and Outlying Islands, including the Cook Group, Tokelau islands, Niue Island and Wester Samoa. Pp. 108. \$1.50. Misc. Pub. No. 110: Rainfal Observations for 1973-Stations in New Zealand and Outlying Islands, including the Cook Group, Tokelau Islands, Nieu Island and Western Samoa. Pp.74. \$1 Wellington: N.Z. Meteorological Service, 1973.) [13 United States Department of the Interior: Geologica Survey. Professional Paper 828: Fuller's Earth and Other Industrial Mineral Resources of the MeigsAttapulgus-Quincy District, Georgia and Florida.
By Sam H. Patterson. Pp. 45 DC: Government Printing Office, 1974.) \$2.40.

Canada: Department of Energy, Mines and ReCanadar. Department of Energy, Mines and Resources. Geologica Survey of Canada. Paper 74-20. Island By D A . \$2 Paper 74 25. The Geom. Maselton. Pp. 10. \$2. Paper 74-25: The Geomorphology of the Swan Paper 74-61: Stratigraphy of the Amoco IOE APuffin, B-90 Well Gtand Banks of Newfoundland. Bu. W. A. M. Jenkins, P. Ascoli, L. F. Jansa and G. L. Williams. Pp. 12. \$2. Paper 74-58: List of Translations in the Library of the Geological Survey of Canada, No. 3. Compiled by C. Joanna Christensen. Pp. iv +43 . \$2. (Ottawa: Information Canada, 1974.) [13 United States Department of the Interior: Geological Survey. Professional Paper 844: Geophysical Investigations of the Pensacola Mountains and Adjacent Glacierized Areas of Antaretica. By John C. Behrendt, John R. Henderson, Laurent Meister and William L. Rambo. Pp. iii $+28+2$ plates. (Washington, DC Government Printing Office, 1974.) \$2.05. [15 Norsk Polarinstitutt. Skrifter Nr. 161: The Billefjorden Fault Zone, Spitsbergen-The Long History of Cutbill, P. F. Friend, D. J. Cobbett. D. W. Holliday, P. I. Maton, J.R. Parker and R. H. Wallis. Pp. 72 (Oslo: Norsk Polarinstitutt, 1974.) [15] United States Department of Agriculture. Index Catalogue of Medicat and Veterinary Zoology. Special Publication No. 3: Ticks and Tickborne Diseases. II. Hosts. Part 1:A-F. Pp. vi + 1-490. Part 2: G-P. Pp. Milured A Doss, Marion M Farr, Katharine F Roach Mildred A. Doss, Marion M. Farr, Katharine F. Roach and George A nastos. (W ashington, DC: US GovernSold in sets only.

Seismic Masking of an Underground Nuclear Explosion-Final Technical Report. By Lawrence D. Porter prepared for Air Force Office of Scientific Research, Arlington, Virginia.) Pp. Xx + 110. (Pasadena, California: Jet Propulsion Laboratory California Institute of Technology, 4800 Oak Grove Drive, 1974.)

Smithsonian Contributions to Zoology, No. 180 : Clearwing Moths of Australia and New Zealand (Lepidoptera: Sesidae). By W. Donald Duckworth and Thomas D. Eichlin. Pp. iii + 45. (Washington, DC: Smithsonian Institution Press, 1974.) For sale by US Government Printing Office.) \$1.15. Canada: Department of Energy, Mines and Re-
sources. Geological Survey of Canada. Paper $75-1$, Part A: Report of Activities, April to October 1974. Pp. $x-1$ 602. (Ottawa: Information Canada, 1975.) \$5. [171 International Atomic Energy Agency, Vienna. Technical Reports Series, No. 158: Recommended Instrumentation for Uranium and Thorium Exploration. Pp. 93. (Vienna: IAEA; London: HMSO, 1974.) 92 schillings; $£ 2.10: \$ 5$. National Research Council of Canada. Associate Committee on Scientific Criteria for Environmental Quality-Subcommittee on Pesticides and Related Its Effects on Canadian Ecosystems and Its Chemistry. Pp. 189. (Ottawa: Publications, NRC. 1974.) \$1. [201 Australia: Commonwealth Scientific and Industrial Research Organization. The Division of Soils Biennial Report, 1972/1973. Pp. 140. (Melbourne: CSIRO, 